\title{
FRACTURES OF THE HAMATUM AND CAPITATUM IN A CHILD: A CASE REPORT
}

\author{
Melih Malkoc, Ozgur Korkmaz, Adnan Kara, Ali Seker, Ismail Oltulu, Serkan Surucu \\ Medipol University Department of Orthopaedics and Traumatology, Istanbul, Turkey

\section{PELOMI GLAVIČASTE I KUKASTE KOSTI KOD DETETA: PRIKAZ SLUČAJA} \\ Melih Malkoc, Ozgur Korkmaz, Adnan Kara, Ali Seker, Ismail Oltulu, Serkan Surucu \\ Medipol univerzitet, Katedra za ortopediju i traumatologiju, Istanbul, Turska
}

\begin{abstract}
Fractures of the carpal bones are rarely seen in children, particularly in the first decade of life. Scaphoid fractures are the most common carpal bone injuries seen during this period of life. A 5-year-old boy was referred to our clinic with right hand and wrist pain and massive swelling. The patient showed limited wrist extension and flexion with pain and swelling, but there was no neurovascular damage. Conventional X-ray and CT scans were performed. The CT results in particular showed clear non-displaced capitatum and hamatum fractures, and a short arm cast was applied. At the 18-month follow-up visit, the patient's fractures were healed with no displacement, and full ROM was achieved with a pain-free motion.
\end{abstract}

\section{SAŽETAK}

Prelomi karpalnih kostiju su retki kod dece, posebno u prvoj deceniji života. Prelomi čunaste kosti su najčešće povrede karpalnih kostiju u ovom periodu života. Petogodišnji dečak je primljen na našu kliniku zbog bola u desnoj ruci $i$ zglobu ručja, kao i zbog masivnog otoka u tom predelu. Kod pacijenta je registrovana ograničena ekstenzija i fleksija u zglobu ručja, praćena bolom $i$ otokom, ali bez znaka neurovaskularnih povreda. Sprovedeno je snimanje X-zracima $i$ CT. Na CT snimcima su se uočili jasni prelomi glavičaste $i$ kukaste kosti, bez dislokacije.i primenjena je gipsana imobilizacija zgloba ručja. Pri pregledu nakon 18 meseci, prelomi su u potpunosti zarasli bez dislokacija i postignut je potpuni opseg pokreta bez osećaja bola.

\section{INTRODUCTION}

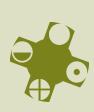

Fractures of the carpal bones are rarely seen in children, particularly in the first decade of life. Scaphoid fractures are the most common carpal bone injuries reported during this period of life (1-4), whereas fractures of the other carpal bones are rarely seen and have generally been described as case reports or small series of patients in the literature $(1,2)(5,6)$.

The main difficulty associated with the diagnosis of paediatric carpal bone fractures is that conventional X-ray radiographies can be inadequate; diagnosis is especially difficult at the time of injury (6). Because of the skeletal immaturity of paediatric patients, it is difficult to visualize the cartilaginous carpal bones with conventional X-ray radiographies (6). Instead, these cartilaginous components are more effectively visualized using imaging techniques such as ultrasonography (USG), CT and MRI (7). Nevertheless, all visualization techniques present different advantages, such as the absence of radiation up-take for USG and MRI and easy accessibility and low cost for CT. Moreover, few reports have described the value of these imaging techniques in young children $(8,9)$.

In this paper, we report the case of a 5-year-old child with a combination of hamatum and capitatum fractures, which is a rare combination in childhood. The purpose of the study was to emphasize the diagnostic value and importance of CT when MRI cannot be achieved because of patient discomfort associated with carpal bone injuries in children.

\section{CASE PRESENTATION}

A 5-year-old boy was referred to our clinic with right hand and wrist pain and massive swelling. The injury occurred when he was playing football at school and fell on his hand. After receiving emergency care at the local hospital, the boy was transferred to our orthopaedic clinic for consultation. 


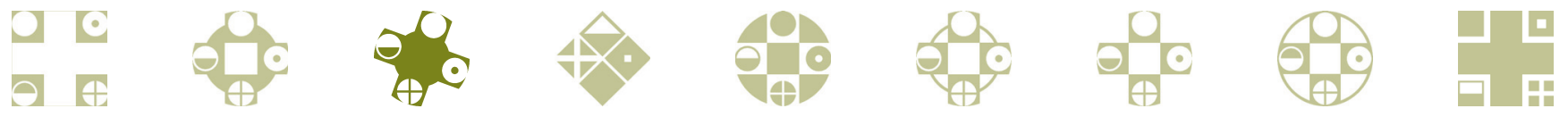
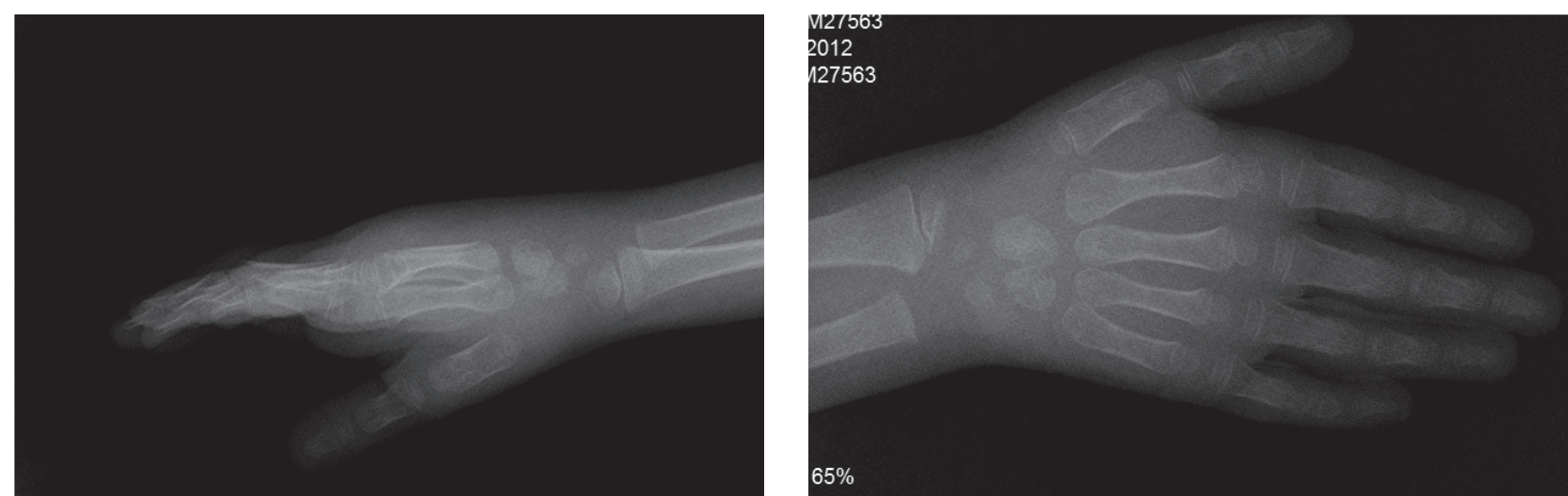

Figure 1: Antero-posterior X-ray of the wrist

Figure 2: Lateral X-ray of the wrist

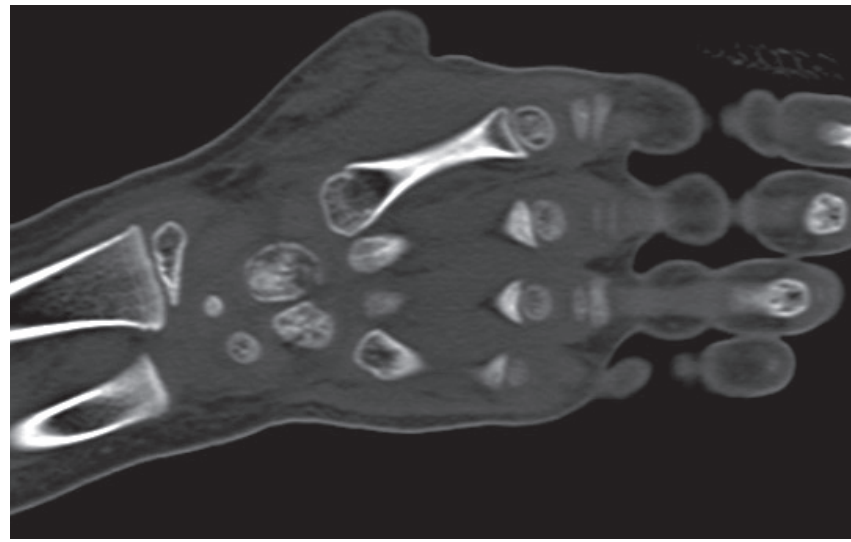

Figure 3: Axial CT image of the wrist

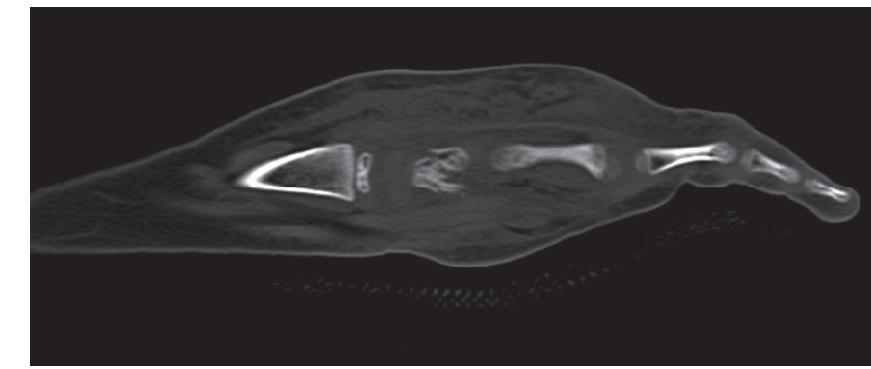

Figure 4: Sagittal CT image of the wrist

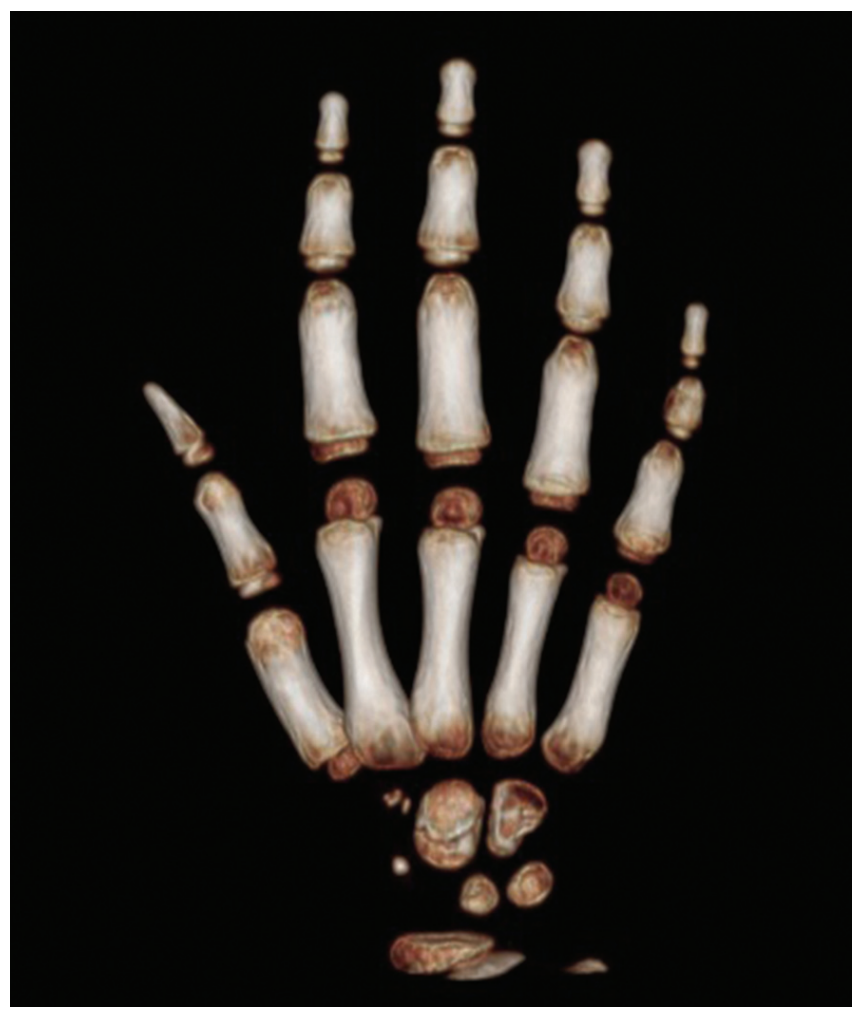

Figure 5: Coronal CT image of the wrist

Figure 6: $3 \mathrm{D}$ reconstructed axial $\mathrm{CT}$ image of the wrist

The patient showed limited wrist extension and flexion with pain and swelling. There was no tenderness in the scaphoid fossa and no neurovascular damage. Conven-

tional X-ray images were taken, although MRI could not be performed because of patient discomfort. Thus, CT images were acquired. The CT results clearly showed non- 
displaced capitatum and hamatum fractures (Figures 1-6), and a short arm cast was applied.

The patient was hospitalised, and after applying the short arm cast, the arm was elevated to prevent compartment syndrome. After 24 hours of observation, there was no evidence of compartment syndrome, and the patient was discharged with recommendations. Four weeks after the trauma, the short arm cast was removed, and exercises to increase the range of wrist motion were recommended. One week later, there was no restriction on wrist range of motion. For this reason, there was no need for additional physical therapy. At the 18-month follow-up visit, the patient showed no wrist pain, and full range of wrist motion was achieved.

\section{DISCUSSION}

Carpal fractures in children are rare, and the scaphoid is the most frequently affected area, whereas the triquetrum is less commonly affected $(5,6,10-13)$. The majority of such cases involve fractures of the scaphoid and the capitatum and often occur in combination with scaphocapitate syndrome (14). Combined fractures of the capitatum and hamatum are extremely rare. There may be 'weak zones' in the capito-hamate and piso-triquetral joints in adults (15), and these bones are often the failure points, rather than the soft tissues, in paediatric peri-articular injuries. Rotational displacement of the capitatum is rare in children when associated with scaphoid fractures. In our patient, the mechanism of injury was usual, as it was associated with a fall onto a dorsiflexed wrist (6).

MRI is a sensitive, reliable and important technique for detecting carpal bone injuries in children, in whom osseous development is progressing and the cartilaginous structure is predominant, particularly when there is a clinical suspicion. MRI may reveal bone marrow changes and cortical disruption and can clearly delineate fracture lines, particularly if the imaging is performed in more than one plane (2). However, we could not use MRI because of agedependent discomfort in our case. Thus, CT may play a role in cases of complex fractures, as this approach is valuable in defining the extent of displacement of the physeal component and in determining the need for internal fixation (16). We used CT to diagnose the extension fracture because of age-dependent discomfort for MRI.

Paediatric delays in diagnosis are common, and the majority of paediatric carpal injuries heal uneventfully with simple cast immobilization. However, displaced fractures may require open reduction and temporary immobilization using either percutaneous Kirschner wires, absorbable pins or conventional screw fixation (17). In our case, the fractures of the hamatum and capitatum were not displaced; therefore, simple cast immobilization treatment was performed.

\section{CONCLUSION}

MRI is the most useful diagnostic tool for the diagnosis of carpal lesions in the skeletal immature child. CT can also be useful for diagnostic studies of paediatric carpal bone fractures because of age-dependent discomfort associated with MRI.

\section{REFERENCES}

1. Kamano M, Fukushima K, Honda Y. Multiple carpal bone fractures in an eleven-year-old. J Orthop Trauma 1998;12:445-8.

2. Obdeijn MC, van Vliet C, van Rijn RR. Capitate and hamate fracture in a child: the value of MRI imaging. Emerg Radiol 2010;17:157-9.

3. Cheow HK, Set P, Robinson S, Balan KK. The role of bone scan in the diagnosis of carpal fracture in children. J Pediatr Orthop B 2008;17:165-70.

4. Bhatnagar G, Crone D, Ahmet H. Paediatric multiple carpal fractures: a case report. Injury Extra 2008;39:247-9.

5. Wulff RN, Schmidt TL. Carpal fractures in children. J Pediatr Orthop 1998;18:462-5.

6. Goddard N. Carpal fractures in children. Clin Orthop Relat Res 2005;(432):73-6.

7. Herneth AM, Siegmeth A, Bader TR, Ba-Ssalamah A, Lechner G, Metz VM, Grabenwoeger F Scaphoid fractures: evaluation with high-spatial-resolution US initial results. Radiology 2001; 220 (1):231-235

8. Partan G, Pamberger P, Blab E, Hruby W Common tasks and problems in paediatric trauma radiology. Eur J Radiol 2003; 48 (1):103-124.

9. Riccabona M, Lindbichler F Trauma radiology in the child. Radiology 2002; 42(3):195-209.

10. Christodoulou AG, Colton CL. Scaphoid fractures in children. J Pediatr Orthop 1986;6:37-9.

11. Light TR. Carpal injuries in children. Hand Clin 2000;16:513-22.

12. Larson B, Light TR, Ogden JA. Fracture and ischemic necrosis of the immature scaphoid. J Hand Surg Am 1987;12:122-7.

13. Letts M, Esser D. Fractures of the triquetrum in chil dren. J Pediatr Orthop 1993;13:228- 31.

14. Sawant M, Miller J Scaphocapitate syndrome in an adolescent. J Hand Surg 2000; 25(6):1096-1099

15. Garcia-Elias M, Abanco J, Salvador E, Sanchez R. Crush injury of the carpus. J Bone Joint Surg Br 1985;67:286-9.

16. Alison M, Azoulay R, Tilea B, Sekkal A, Presedo A, Sebag G. Imaging strategies in paediatric musculoskeletal trauma. Pediatr Radiol 2009;39 Suppl 3:414-21.

17. Pelto-Vasenius K, Hirvensalo E, Rokkanen P: Absorbable pins in the treatment of hand fractures. Ann Chir Gynaecol 1996;85:353-358, 